\title{
RETHINKING HEIDEGGER'S DWELLING THROUGH ARABIC LINGUISTICS
}

\section{Mustapha Hashem EI Moussaoui}

Universitat Politecnica de Valencia

Spain

musel@doctor.upv.es

\begin{abstract}
Inhabiting a space or dwelling has been a debatable terminology in architectural theory \& practice. Martin Heidegger's conference paper "Building dwelling thinking" is a major philosophical work that influenced architects in the 20th century. The philosopher interpreted the word as an etymological archaeologist, working on the word's essential meaning until he related it to, Being-in-this-world and Being-towards-death. In this research, we examine the term "dwelling" through the Arabic parables "Maskan" and "Manzel" to reach a more comprehensive understanding that will unveil its essential meaning in its local cultural context. Moreover, we base our research on a survey answered in Lebanon, on the meaning of the word Maskan in its contemporary form, while linking it to Heidegger's etymological findings. Our results explicitly an Arabic term used that describes a different phenomenon in other cultures.
\end{abstract}

KEYWORDS: Heidegger, Dwelling, Etymology, Throwness, Arabic Linguistics

\section{INTRODUCTION}

It may seem rather obvious that a structure is essentially designed for man's dwelling [1]. However, the philosopher Martin Heidegger argues that not all structures and buildings are designed for dwelling, as is the case for factories and offices [2]. Heidegger's "building dwelling and thinking," which he first gave at a conference in Darmstadt in 1951, is considered one of the most influential texts in the 2oth century due to its remarkable interpretation perspective to architecture and the act of inhabiting a space. Contemporary architectural thinking extracts from his text and revolves around the understanding of building and dwelling as more or less abstract forms of being, without taking into account the people inhabiting space. Heidegger claims that we have forgotten to dwell in the same way as we have forgotten what it means to be in the original sense of the word. In many of his works, Heidegger seems to presuppose that the further you go back, or the deeper you dig down into the most profound layers of language, especially Greek and German, the more accurate are the meanings you get hold of and the more we will know about how things are. However, some Heidegger's thought has been discussed in some other researches, but only a few of them talking about his writing about dwelling, and none of them discuss it from the linguistic perspective [3][4][5][6][7].

One of the terms Heidegger studied is the word 'dwelling.' He started by questioning the word "Bauen," building. Heidegger understands as building, Bauen, in the form of dwelling, Wohnen, and this pre- supposition explains why he can do without any architectural expressions and dismiss dwelling in buildings as something secondary to the philosophical discourse. By Heideggerian means, the dwelling phenomenon through the Arabic parables will be studied, relating it to the etymological essence of the word that will lead us to another understanding of the word "dwelling" in Arabic linguistic context. Understanding the word dwelling in its cultural context will give us a better insight into the essential meaning of architecture in the indigenous cultural context. We will start by retaining the etymology of the word "dwelling" through the Qur'anic text- as the Quran is labeled as the grammatical origin of the Arabic language- and then we will disseminate some answers of a survey done on the essence of the word dwelling, and what it means, in its contemporary cultural context.

\section{METHODS}

To better understand the phrase in its Arabic form, we dug into etymology and its essential meaning in its contextual language, hence, referring to the Quran as a source of essential meaning. Moreover, we performed a survey in Lebanon to represent the word in its contemporary use. Finally, we compare our findings to Heidegger's writings.

\section{DISCUSSION}

\section{HEIDEGGER-IAN DWELLING}

In the Heideggerian understanding of dwelling, Heidegger indicated in his conference "Building 
Dwelling Thinking" by begging the question, "what is it to dwell?" He questioned the difference between the working place and the actual dwelling space. It is a matter of space perception, which we deal with daily [8].

Bridges and hangars, stadiums, and power stations are buildings but not dwellings; railway stations and highways, dams, and market halls are built, but they are not dwelling places. Even so, these buildings are in the domain of our dwelling. That domain extends over these buildings and yet is not limited to the dwelling place. The truck driver is at home on the highway, but he does not have his shelter there; the working woman is at home in the spinning mill but does not have her dwelling place there; the chief engineer is at home in the power station, but he does not dwell there. These buildings houseman. He inhabits them and yet does not dwell in them. In today's housing shortage, even this much is reassuring and to the good; residential buildings do indeed provide shelter; today's houses may even be well planned, easy to keep, attractively cheap, open to air, light, and sun, but do the houses in themselves hold any guarantee that dwelling occurs in them?

(1971: 1)[9].

This paragraph resonates with Heidegger's idea of nearness. He notes that all distances in time and space are shrinking. The man now reaches overnight, by plane, places which formerly took weeks and months of travel, yet the frantic abolition of all distances brings no nearness, for nearness does not consist in shortness of distance. According to Heidegger, one can live in a building daily but not feel at home or near it. To dwell in a house is not merely to be inside it spatially but belong there, to have a familiar place there. He adds that the words "residential" and "housing" may be interpreted to refer to the new production system and not their relation to people. To Heidegger, this contemporary use of language reflects the production system where developers create inhabitation space for a market of unknown consumers. Such a procedure devalues the essential meaning of dwelling because building should not be viewed as just a process of coming up with consumer products. The contemporary relation between building and dwelling suggests an unfavorable comparison between past and present [10].

'For building isn't merely a means and a way towards dwelling - to build is in itself already to dwell' $(1971,2)$ [9].

\section{HEIDEGGER'S ETYMOLOGY}

According to Heidegger, an authentic relationship between building and dwelling is found in those words' etymology. As Heidegger has suggested, both words share the same root origin in Old German. It was not a surprise to him as both words were previously understood as the same thing [11]. Heidegger continues:

Bauen originally means to dwell. Where the word bauen still speaks in its original sense. It also says how far the essence of dwelling reaches. That is bauen, buan, bhu, beo are our word bin in the versions: ich bin, I am, du bist you are, the imperative form bis, be. What then does ich bin mean? The old word bauen to which the bin belongs, answers: ich bin, du bist mean I dwell, you dwell. The way in which you are, and I am, the manner in which we humans are on the earth, is buan, dwelling [. . . The old word bauen which says that man is insofar as he dwells, this word bauen, however also means at the same time to cherish and protect, to preserve and to care for, specifically to till the soil, to cultivate the vine. (1971: 147) [9].

Heidegger attempts to illustrate how the contemporary use of the words changed the conception and behavior; Building as construction, and dwelling as living. On the other hand, building and dwelling, combined together, are central to human existence. The existential I of where we belong 'I am' and 'you are' 'ich bin' 'du bist' means I dwell, you dwell. He is suggesting that building and dwelling sit in the core of existence. Living in a house and nurturing the house is an affirmation of being. According to his etymology, when we mention the 'I am,' 'you are,' 'we are,' we are reassuring the extreme importance of building and dwelling through human existence [12][13][14]. Therefore, construction and land cultivation are other forms of acknowledgment of human presence in languages. Later on, after stating the etymology of the word 'bauen,' he explores the interrelated word 'wohnen' 'dwelling' [15], and this is a quote:

The Old Saxon wuon, the Gothic wunian, like the old word bauen, mean to remain, to stay in a place. But the Gothic wunian says more distinctly how this remaining is to be experienced. Wunian means to be at peace, to be brought to peace, to remain in peace. The word for peace, Friede, means the free, das Frye; and fry means preserved from harm and danger, preserved from something, safeguarded. To free actually means to spare (1971:2) [16].

While 'bauen' is more of an existential reassuring through the building and cultivating, the word 'wohnen' relates to the relaxed state of being into the word dwelling. At this point in the research, the Arabic parables will be looked into for relations and comparisons between etymology and linguistic origins.

\section{DWELLING IN THE ARABIC PARABLES}

To start with, the word "Dwelling" in Arabic is mostly related to "Māskan" in its direct etymological understanding. Still, if we derive the word from its essence, we reach some remarkable material. The word "Māskan" is derived from "Skoon," which means to remain still, to remain calm, and to be at ease from pain. In the Arabic language, any painrelieving drug is called "Musāken," which is a verb phrase of "to give relief," or the action of relieving pain. The verb can also be used as an act of putting off, for example, "Askana Al-Nar" or "to put-off fire." Moreover, the term "Sakinah" "سَكينة "with raising the "S" by "" wis defined as; calm(ness), 
peace (fulness), (re)assurance, (hearts) ease, etc. [17]. On the other hand, the word "Sokoon" is also prominent in the Arabic language as it is a modulation sign used in every word. The "Sokoon" is a small circle placed above the letters you want to keep silent and un-pronounced. The "Sokoon," "०" is one of the five modulation symbols used in the Arabic language to facilitate the pronunciations of words and their connotation.

Another use of the term in its plural form is the word "Masākeen," which refers to helpless people who are deprived and unable to sustain their daily existence. Dwelling places are also pronounced and written "Masāken," a plural word form of "Maskan." In the Quran, the word "Maskan" highlights a new dimension of understanding the word dwelling.

In chapter 7, verse 189, the Quran mentions "Maskan."

He who created you from one soul and created from it its mate that he might dwell in security to her"[18].

In the previous verse, we can apprehend that dwelling in space is not a physical form of architecture; it is described as an emotional/mental state. The dwelling feeling of being at an ease of pain is a mental state that every being strives to achieve. It is the ease of pain and relief from hardships. The state of pain release and dwell "Maskan" are related to physical architecture and an emotional state between couples.

Another word used in the Arabic parables for a house is "Manzel." "Manzel" is derived from "Nazal" and "nozol," which means to settle or to go down.

"Nozol" is also used as a form of transcendental knowledge. "Nozol" is used when describing the divine knowledge being sent down from heavens to earth to God's chosen people, or prophets, a form of knowledge being sent down to humans. "Manzel" is used as a representation of a house. The phrase itself does not portray the same emotional depth of inhabiting space as "Maskan." "Manzel" is used as a physical inhabitation of area, a form of measurable entity, whereas "Maskan" represents the metaphysical form of inhabited space, a spatial dimension that the soul gets familiar with its ambiguous scale. The "Maskan" isn't necessarily defined by any physical boundary but may be recognized by a poetic sense; a smell, texture, a woven pattern, or another intimate being representing the space. Gaston Bachelard speaks about the poetics of space as a "hide-and-seek places where the mind can go on holiday for a while and think about nothing, which means everything; havens where the soul can pause in silence, and free itself to dream"[19].

\section{"MASKAN" IN CONTEMPORARY UNDERSTANDING}

After the etymological reading on "Dwelling" in the Arabic parables as a linguistic means, a survey was conducted in the research about dwelling, in its current use and understanding to the Lebanese people. The questionnaire has been conducted on some 200 participants disseminated between Beirut - is the capital and the largest city in Lebanon, with an estimated population in its greater area to around 2.2 million people - and Eastern Bekaa - located on the anti-Lebanese mountains that separate Syria from Lebanon. The region is most famous for its agricultural lands. The survey bared 25 questions regarding "Maskan," spanning through the importance, meaning, essentials, location, and lacking a dwelling space. One of the questions which is directly related to the "Maskan" is "What does the word "Maskan" mean to you?" The most responded axiom to the word "Maskan" was security, followed by comfort. Other answers varied from stability, warmth, family, reassurance, calm, house, and quietness (Fig. 1).

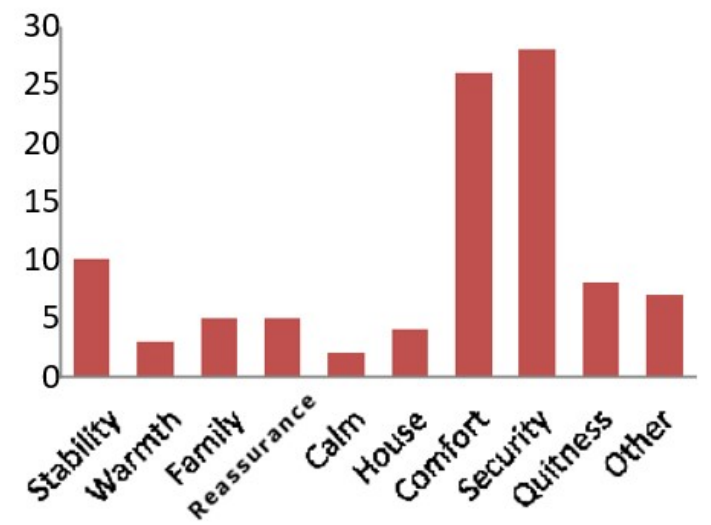

Figure. 1. Percentage answers on the relevance of the word "Maskan."

\section{"THROWNESS" INTO EXISTENCE}

Heidegger in 'Being and Time' -written in 1927 introduced the concept of 'Geoworfenheit,' or 'throwness'[20]. The concept describes a human's existence as "being thrown," 'Geworfen' into the world. 'Geworfen' describes the ambiguous nature of 'Dasein' that relates the past with the present. The past by 'Being-toward-death' becomes part of 'Dasein.' Being-towards-death refers to a process of growing through the world where a certain foresight guides the Dasein towards gaining an authentic perspective. It is provided by dread or death. Time analysis is revealed as a threefold condition of Being-time; the present, the past, and the future. Understanding the ambiguous term, 'Dasein' is regarded as a state of 'Geoworfenheit,' or 'Throwness' in its present form with all its sufferings, frustrations, and sorrows. To Heidegger, the hardships and frustrations are born due to the unchosen social conventions, politics, kindship, and duties. The essential idea of one's existence is a demonstration of 'Geoworfenheit.' The idea of the past as a milieu that we don't choose, yet at the same time, not exclusion deterministic or obligatory, results in the notion of 'Geoworfenheit.' In a weird manifestation the notion of 'throwness' leaves humans with a contradictory or perhaps paradoxical passage to freedom [16]. 


\section{HEIDEGGER AND THE ARABIC PARABLES}

Heidegger, in his book "Being and Time," expresses how humans suffer the throwness 'Geoworfenheit' to the existence, by being born into social conventions, politics, kindship, and duties not of their choosing. The Arabic word for "Dwelling," "Māskan" or to relieve pain is a complement to this notion, as the Arabic term inscribes how we run away from our daily hardships into our homes, dwelling spaces, and companion. The "Māskan" is a painrelieving act from the 'Geoworfenheit' into existence, expressed in the German word 'Wohnen.' Being in "skoon" from our daily hardships is by going back into our comfort spaces before returning to the harsh world. 'Being-towards-death' is a recurring process, running away from the external suffering into our comfortable interior pain-relieving dwelling spaces.

\section{CONCLUSION}

Inhabiting a space has the primary need for human beings. This action of inhabiting a space has been stated in different terms through cultures. Terms of linguistics evolved into words due to the need to call the specific action; hence, the action created linguistic words that define it with immense emotions. The purest forms of distribution have been made to call this action. Thus, Heidegger studied the etymology of words to pursue its purest form of meaning, the foundation of its essence, the emotional necessity to the word, and whether a verb or a noun. Heidegger studied the words; 'bauen' to understand the root significance of the building and 'Wohnen' as an action of cultivating the land. In the article, the word dwelling is studied in the Arabic parables in an exploration duty to find its essence in its cultural context. According to Heidegger, the words 'Wohnen' and 'Bauen' expressed the acts of building and cultivating in the same sense.

Furthermore, he adds 'ich bin,' 'du bist' or 'I am,' 'you are,' 'I dwell,' 'you dwell.' Hence, existing and dwelling both imply the same thing in Old German. Every culture has its linguistic preferences, and such linguistics express certain emotional intensity describing a specific work. "Māskan" or dwelling in Arabic has been rooted back to its essential meaning. Hence the word etymologically means to be in peace, remain silent, and be at ease from pain. The word describes an intense, relaxed emotional state, whereas, in the Quran, the word dwelling is related to an emotional state between happy couples.

In a survey done in Lebanon, the word dwelling, 'Maskan', mostly referred to security and comfort. Most answers related the word of "Maskan" with "security" "comfort" and "stability".

Heidegger, in another book he published, "Being and Time," mentions the philosophical terminology "Geoworfenheit" or "throwness." The term means being thrown into existence with all its present forms of suffering, frustrations, and sorrows. In Arabic linguistics, the word "Māskan" expresses the three German words introduced by Heidegger; "Geoworfenheit," "Bauen," and "Wohnen." The words mined by Heidegger are described in "Maskan" through; Inhabiting a space with its original form of emotional state - far away from the contemporary use of "building"- Being in peace, and the ease of pain from the external world suffering or "Geoworfenheit."

\section{REFERENCES}

[1] P. Cloke and J. Owain, "Dwelling, place, and landscape: an orchard in Somerset," Environment and planning A, vol. 33, no. 4, pp. 649666, 2001.

[2] M. Heidegger, "Poetically Man Dwells," Canadian Journal of Psychoanalysis, vol. 10, no. 2, pp. 233-236, 2002.

[3] R. Chia and R. Holt, "Strategy as Practical Coping: A Heideggerian Perspective," Organization studies, vol. 27, no. 5, pp. 635-655, 2006.

[4] M. Davidson, "Displacement, Space and Dwelling: Placing Gentrification Debate," Ethics Place and Environment (Ethics, Place \& Environment (Merged with Philosophy and Geography)), vol. 12, no. 2, pp. 219-234, 2009.

[5] D. Ladkin, "When deontology and utilitarianism aren't enough: How Heidegger's notion of 'dwelling' might help organisational leaders resolve ethical issues," Journal of Business Ethics, vol. 65, no. 1, pp. 87-98, 2006.

[6] D. Seamon, "Concretizing heidegger's notion of dwelling: The contributions of thomas thiis -evensen and christopher alexander," Building and dwelling [Bauen und wohnen], pp. 189-202, 2000.

[7] C. Norberg-Schulz, "Heidegger's thinking on architecture," Perspecta, vol. 20, pp. 61-68, 1983.

[8] A. Sharr, Heidegger for Architects. London: Taylor \& Francis, 2007.

[9] M. Heidegger, "Building Dwelling Thinking," Poetry, Language, Thought, vol. 154, 1971.

[10] J. Holst, "Rethinking Dwelling and Building," ZARCH: Journal of Interdisplinary Studies in Architecture and Urbanism, vol. 2, pp. 52-61, 2014.

[11] J. W. Alvis, “Making sense of Heidegger's 'phenomenology of the inconspicuous' or inapparent (Phänomenologie des Unscheinbaren)," Continental Philosophy Review, vol. 51, no. 2, pp. 211-238, 2018.

[12] T. D. Okoro, Modernity and Destining of Technological Being. Peter Lang Publishing Group, 2016.

[13] O. Karamercan, "Heidegger's Topology of Language: Language and Dwelling," University of Tasmania, 2018. 
[14] M. El Moussaoui, "Phenomenology in Pure Aesthetics," Journal of Civil Engineering and Architecture, vol. 14, pp. 168-173, 2020.

[15] J. Malpas, Heidegger and the Thinking of Place: Explorations in the Topology of Being. Cambridge: MIT Press, 2012.

[16] H. Martin, Being and Time. New York: Harper and Row, 1962.
[17] Mujamaā al-Lugha Al Arabia b āl Kahera 5th Edition. Al Muājam Al wasit, 1960.

[18] M. A. . A. Haleem, The Qur'an. Oxford: Oxford University press, 2005.

[19] B. Gaston, The Poetics of Space. Boston: Beacon Press, 1958.

[20] D. O. Dahlstrom, The Heidegger Dictionary. London: A\&C Black, 2013. 